\title{
Etika Konsumsi Islami dari Pegawai SMU di Kota Bandung
}

\author{
IMA AMALIAH ${ }^{1}$, AAN JULIA $^{2}$, WESTI RIANI $^{3}$ \\ 1,2,3 Program Studi Ilmu Ekonomi Unisba, Jl. Tamansari No.1 Bandung \\ email: ${ }^{1}$ amalia.razi@gmail.com, ${ }^{2}$ mutiah_aan@yahoo.com, ${ }^{3}$ westiriani@yahoo.com
}

\begin{abstract}
The aim of this paper is to find out how is the Islamic consumption behavior of the employees working at the Senior High Schools in Bandung. This paper used the quantitative descriptive approach with survey method. The respondents were 100 people taken from all the employees (teachers and administration staffs ) working at 10 selected Senior High Schools. The result shows that there was no significant difference of the consumption behavior between the employees working at Islamic education institutions and public institutions in Bandung. In general, the Islamic consumption behavior from the employees working around Senior High Schools environment was categorized high mainly for the indicator of selecting the halal brand food, good and useful in the consumption. However, there was still the behavior directing to useless and excessive behavior caused by the effect of advertisement, discount and personal prestige. There fore, internalization of the religious values in all aspects of life as well as the improvement of knowledge in which an individual can minimize the consumptive behavior that engenders him or her as well as their whole life is considerably required.
\end{abstract}

Keywords: islamic consumption ethics, religion value, happiness

\begin{abstract}
Abstrak. Tujuan dari paper ini untuk mengetahui bagaimana perilaku konsumsi Islami dari pegawai yang bekerja di SMA di Kota Bandung. Paper ini menggunakan pendekatan deskriptif kuantitatif dengan metode survei. Jumlah responden 100 orang yang diambil dari seluruh pegawai (guru, tata usaha, dan staf administrasi) yang bekerja di sepuluh SMA terpilih. Hasilnya, tidak ada perbedaan signifikan perilaku konsumsi dari pegawai yang bekerja di lembaga pendidikan Islam dan umum di Kota Bandung.Secara keseluruhan, perilaku konsumsi Islami dari para pegawai yang bekerja di lingkungan pendidikan SMA di Kota Bandung terkategori tinggi, terutama untuk indikator memilih barang yang halal dan baik serta maslahah dalam konsumsi. Namun,masih ada perilaku pegawai yang mengarah pada tindakan mubazir dan berlebihan yang disebabkan karena pengaruh iklan, potongan harga, serta gengsi pribadi. Perlu adanya internasilisasi nilai-nilai agama di berbagai lini kehidupan serta peningkatan pengetahuan agar seorang individu dapat mengurangi perilaku konsumtif yang dapat membahayakan dirinya dan kehidupan secara keseluruhan.
\end{abstract}

Kata kunci: etika konsumsi Islami, nilai agama, maslahah

\section{Pendahuluan}

Islam telah memberikan tatanan yang sangat komprehensif bagi seluruh aktivitas manusia, tidak hanya dalam aktivitas ibadah, tetapi juga muamalah (Effendi, 2013). Dalam kegiatan konsumsi, Islam telah mengaturnya sedemikian rupa agar manusia tidak terjatuh dalam kerusakan dan kesesatan. Dalam AlQuran, Allah telah mengingatkan manusia untuk melakukan kegiatan konsumsi secara seimbang serta berlaku adil (QS Al-Baqarah ayat 168 dan 173). Begitupun dalam hadis, Rasulullah Saw banyak mengajarkan manusia untuk berlaku secukupnya dalam kegiatan konsumsi. Namun, dalam faktanya masih banyak orang yang berlaku boros serta berlebih-lebihan yang mengakibatkan kerawanan pangan di berbagai tempat yang kemudian berakibat pada tidak terkendalinya harga barang-barang di pasaran.

Dari hasil pengamatan di lapangan terlihat jelas bahwa trend harga barang secara umum terus menunjukkan peningkatan yang signifikan dari waktu ke waktu. Kondisi ini terkait erat dengan perubahan perilaku masyarakat dalam berkonsumsi. Adanya

Received: 8 Oktober 2014, Revision: 3 Juni 2015, Accepted: 9 Juni 2015

Print ISSN: 0215-8175; Online ISSN: 2303-2499. Copyright@2015. Published by Pusat Penerbitan Universitas (P2U) LPPM Unisba Terakreditasi SK Kemendikbud, No.040/P/2014, berlaku 18-02-2014 s.d 18-02-2019 
berbagai kemudahan yang diciptakan oleh para produsen dan pedagang serta berbagai kemajuan teknologi perbankan cenderung mendorong masyarakat lebih konsumtif dalam memenuhi berbagai macam keinginannya. Peningkatan pendapatan jarang disikapi oleh masyarakat dengan meningkatkan tabungannya, sehingga marginal propensity to save (MPS) di masyarakat tetap rendah.

Fenomena ini terjadi pula di lingkungan pendidikan SMA di Kota Bandung. Di satu sisi, sertifikasi guru telah mengangkat kesejahteraan para guru. Namun di sisi lainnya, peningkatan pendapatan cenderung membuat para guru lebih konsumtif di dalam pengeluarannya. Peningkatan pendapatan seringkali digunakan untuk membeli barangbarang yang tidak ada relevansinya dengan peningkatan kegiatan belajar mengajar. Padahal Islam telah memberikan tatanan nilai-nilai yang mengatur perilaku etis keagamaan dalam berkonsumsi yang akan membawa masyarakat pada keselamatan di dunia dan akhirat.

Melihat persoalan di atas, maka paper ini akan menelaah tentang bagaimana konsumsi Islami dari para pegawai di lingkungan pendidikan SMA di Kota Bandung.

\section{Apa itu Konsumsi?}

Konsumsi berasal dari bahasa Belanda yaitu consumptie, artinya suatu kegiatan yang dilakukan oleh seorang individu yang bertujuan untuk mengurangi atau menghabiskan daya guna suatu benda, baik berupa barang maupun jasa untuk memenuhi kebutuhannya (Case \& Fare, 2010). Selain itu, konsumsi dapat didefinisikan juga sebagai perilaku seorang individu dalam menggunakan dan memanfaatkan barang dan jasa guna memenuhi kebutuhan hidupnya (Sarwono, 2011). Dalam pengertian yang lebih luas, konsumsi tidak hanya menyangkut penggunaan barang seperti makan, minum, memakai kendaraan dan lainnya tetapi juga memanfaatkan barang dan jasa guna memenuhi kehidupannya (Putong, 2008). Dengan demikian, segala aktivitas, baik menggunakan ataupun memanfaatkan guna suatu barang, dapat dikatakan konsumsi.

\section{Konsep Islami dalam Berkonsumsi}

Seorang individu akan melakukan aktivitas konsumsinya karena individu yang bersangkutan melihat dua hal, yaitu adanya kebutuhan serta manfaat yang akan diberikan oleh barang atau benda yang dikonsumsinya
(Karim, 2007). Artinya, kebutuhan dan manfaat memiliki hubungan interdependensi (saling bergantung) dengan kegiatan konsumsi itu sendiri. Seseorang yang lapar pasti butuh makanan, maka dengan makanan ia akan mendapatkan manfaat yaitu tenaganya pulih kembali, sehingga dapat menjalankan seluruh kegiatannya. Dalam pandangan Islam, pemenuhan kebutuhan merupakan hal yang sangat dianjurkan karena di dalamnya terdapat maslahah (manfaat) yang lebih besar. Sebaliknya, pengabaian berbagai kebutuhan akan melahirkan kemudharatan yang lebih besar bagi kehidupan manusia itu sendiri (Kara, 2012).

Kebutuhan dalam pandangan Islam adalah keinginan manusia untuk menggunakan sumber daya yang tersedia guna mendorong pengembangan potensi dirinya dengan tujuan membangun dan menjaga bumi beserta isinya. Manusia merupakan makhluk yang tersusun dari berbagai unsur (jiwa dan raga, jasmani dan rohani) di mana unsur-unsur tersebut memiliki keterkaitan yang erat satu dengan yang lainnya. Tiap-tiap unsur dalam diri manusia memiliki kebutuhan yang berbeda-beda namun terkait satu dengan yang lainnya.

Raga manusia memerlukan makanan dan minuman. Terpenuhinya kebutuhan raga akan berdampak pada kebahagiaan jiwa bagi manusia itu sendiri. Begitupun sebaliknya, jiwa yang bahagia akan mendorong manusia untuk berusaha lebih maksimal, sehingga efeknya manusia dapat memenuhi kebutuhan raganya lebih baik dan lebih optimal (AlGhazali, 2009). Dengan demikian, Islam mengajarkan manusia untuk memakan makanan yang tidak hanya halal tetapi juga harus baik (QS Al-Maidah: 88).

Selain itu, dalam berkonsumsi harus dipertimbangkan manfaatnya (maslahah). Dalam pandangan Asy-Syatibi, maslahah artinya sesuatu yang baik dan dapat diterima akal yang sehat (Kara, 2012). Artinya, akal dapat mengetahui dengan jelas kemaslahatan tersebut. Menurut Amir Syarifuddin dalam Kara (2012), ada dua bentuk maslahah yaitu: pertama, mewujudkan manfaat, kebaikan dan kesenangan untuk manusia yang disebut jalb almanafi (membawa manfaat). Kebaikan dan kesenangan ada yang dirasakan langsung oleh orang melakukan sesuatu perbuatan yang diperintahkan, tetapi ada juga kebaikan dan kesenangan dirasakan setelah perbuatan itu dilakukan, atau dirasakan di hari kemudian (akhirat). Segala perintah Allah Swt berlaku 
untuk mewujudkan kebaikan dan manfaat seperti itu. Kedua, menghindarkan umat manusia dari kerusakan dan keburukan yang disebut dar'u almafasid. Kerusakan dan keburukan pun ada yang langsung dirasakannya setelah melakukan perbuatan yang dilarang, ada juga yang merasakan sesuatu kesenangan ketika melakukan perbuatan dilarang itu, tetapi setelah itu yang dirasakannya adalah kerusakan dan keburukan (Kara, 2012: 173). Dengan demikian, kegiatan konsumsi yang dilakukan manusia hendaknya memberikan manfaat ,tidak hanya dalam kehidupan manusia di dunia, tetapi juga di akhirat nanti.

\section{Pandangan Islam tentang Kebutuhan dan Keinginan}

Motif dasar manusia beraktivitas adalah untuk memenuhi berbagai macam kebutuhan hidupnya. Menurut Maslow, ada beberapa tingkatan (hierarki) kebutuhan manusia yang tersusun dari kebutuhan yang paling rendah yaitu kebutuhan fisiologis (kebutuhan makanan, minuman, pakaian, seks dan lainnya) sampai kebutuhan tertinggi (kebutuhan akan kekuasaan). Menurut Maslow, pemenuhan kebutuhan tersebut harus dilakukan secara berjenjang (Robbins, 2009). Kebutuhan seorang individu akan meningkat jika tingkatan kebutuhan yang lebih rendah sudah terpenuhi. Jika kebutuhan primer sudah terpenuhi maka manusia akan memikirkan kebutuhan sekunder maupun tersier.

Sementara itu, Imam Al-Ghazali (seorang sufi) mengungkapkan, yang menjadi kebutuhan dasar manusia adalah apa yang tersurat dalam Maqashid Syariah, yaitu terpenuhinya lima perkara, yaitu kebuhan beragama (al-dien), kebutuhan jiwa (nafs), kebutuhan akal (aql), kebutuhan keturunan (nasl), dan kebutuhan harta benda (maal). Menurut Imam Al-Ghazali (2011), kebutuhan paling mendasar bagi manusia adalah kebutuhan agama, sedangkan kebutuhan akan harta adalah kebutuhan paling akhir. Harta hanyalah alat (mean) untuk mencapai tujuan yang sesungguhnya, yaitu beribadah kepada Allah (Capra, 2008).

Jika dibandingkan antara pemikiran Maslow dengan pemikiran Imam Al-Ghazali, maka pemikiran Imam Al-Ghazali terlihat jauh lebih komprehensif dibandingkan pemikiran Maslow (ekonom kontemporer). Maslow hanya menyoroti kebutuhan manusia dari sisi material dan nonmaterial saja. Sedangkan
Imam Al-Ghazali memasukkan kebutuhan spiritual keagamaan sebagai kebutuhan dasar manusia di samping kebutuhan material dan nonmaterial. Kebutuhan spiritual keagamaan merupakan kebutuhan pokok manusia yang dapat menuntunnya membedakan mana yang benar dan salah, mana yang hak dan batil, mana hak dan kewajiban. Dengan agama, maka individu tidak hanya merasakan indahnya pemuasan kebutuhan fisik, tetapi juga menambah rasa syukur pada Tuhannya (Chapra, 2008).

Dalam pandangan Islam, antara kebutuhan dan keinginan adalah berbeda. Dasar dari pemenuhan kebutuhan adalah maslahah (manfaat bagi manusia tidak hanya secara material tetapi juga moral dan spiritual). Sementara keinginan, dasar pemenuhannya adalah hasrat (nafsu), bukan manfaat. Dengan demikian, tidak semua keinginan harus dipenuhi oleh seorang individu. Hanya keinginan keinginan yang memberikan manfaat (maslahah) yang harus dipenuhi oleh setiap individu. Kemampuan seorang individu dalam membedakan antara kebutuhan (need) dengan keinginan (want) maka individu dapat mengerem dari tindakan berlebihlebihan, pemborosan, serta penghamburan sumber daya. Berikut gambaran karakteristik keinginan dan kebutuhan:

Tabel 1

\section{Perbedaan antara Keinginan dan Kebutuhan}

\begin{tabular}{|l|l|l|}
\hline $\begin{array}{c}\text { Karakter- } \\
\text { istik }\end{array}$ & \multicolumn{1}{|c|}{ Keinginan } & Kebutuhan \\
\hline Sumber & $\begin{array}{l}\text { Hasrat (nafsu) } \\
\text { manusia }\end{array}$ & $\begin{array}{l}\text { Fitrah } \\
\text { manusia }\end{array}$ \\
\hline Hasil & Kepuasan & $\begin{array}{l}\text { Manfaat \& } \\
\text { Berkah }\end{array}$ \\
\hline Ukuran & $\begin{array}{l}\text { Preferensi / } \\
\text { selera }\end{array}$ & Fungsi \\
\hline Sifat & Sunyektif & Obyektif \\
\hline $\begin{array}{l}\text { Tuntunan } \\
\text { Islam }\end{array}$ & $\begin{array}{l}\text { Dibatasi/ } \\
\text { dikendalikan }\end{array}$ & Dipenuhi \\
\hline
\end{tabular}

Sumber: buku Ekonomi Islam (PPEI, 1999); Asytuti (2011)

\section{Jenis-jenis Kebutuhan Manusia Menurut Islam}

Manurut Asy-Syatibi, terdapat tiga tingkatan kebutuhan yang ingin dicapai oleh setiap individu dan menjadi motivator bagi seorang individu untuk mengusahakannya, yaitu kebutuhan daruriyat (kebutuhan primer), kebutuhan hajiniyat (kebutuhan sekunder) dan kebutuhan tahsiniyat (kebutuhan tertier) 
(Kara, 2012):

Kebutuhan Dharuriyat (kebutuhan primer) adalah sesuatu yang seharusnya ada untuk menjamin kemaslahatan agama dan dunia. Adapun yang termasuk ke dalam maslahah dharuriyat adalah agama (al-dien), jiwa (Nafs), akal $(A q l)$, keturunan (nasl) dan harta (Al-Maal) di mana kelimanya merupakan satu kesatuan yang tidak dapat dipisahkan. Bila ada satu saja kebutuhan yang diabaikan, maka akan menimbulkan ketimpangan pada kehidupan manusia. Tidak terwujudnya aspek maslahah dharuriyat dapat merusak kehidupan manusia baik di dunia maupun di akhirat secara keseluruhan. Kebutuhan dharuriyat ini harus menjadi prioritas utama bagi seorang Muslim dalam melakukan aktivitas pekerjaanya. Seorang pegawai Muslim harus mempertimbangkan kelima aspek kebutuhan dalam menerima dan menekuni pekerjaanya sehingga tercipta kehidupan yang seimbang.

Kebutuhan hajiyat (kebutuhan sekunder) berfungsi melengkapi aspek kebutuhan dharuriyat supaya lebih kokoh. Misalnya pemilikan kendaraan roda empat merupakan kebutuhan pelengkap yang dapat memberikan kenyamanan yang lebih besar bagi pemiliknya. Tidak terpenuhinya kebutuhan ini tidak menyebabkan manusia dalam kemudharatan. Dalam kegiatan ibadah yang terkategori kebutuhan hajiyat adalah ibadah sunnah yang berfungsi menyempurnakan ibadah wajib. Pengabaian terhadap kebutuhan hajiyat tidak sampai merusak kelima unsur pokok tetapi akan membawa kesulitan manusia sebagai mukalaf dalam merealisasikannya.

Kebutuhan tahsiniyat (kebutuhan tersier) berfungsi menambah keindahan dan kesenangan hidup. Maslahah tahsiniyat diperlukan untuk menjaga kehormatan hidup yang melibatkan kemuliaan akhlak dan adat yang baik. Kebutuhan tahsiniyat diperlukan untuk menjamin kelancaran hidup manusia. Pengabaian terhadap unsur tahsiniyat mengakibatkan aktivitas pemeliharaan lima unsur tidak sempurna.

Dengan demikian, motivasi seorang individu dalam melakukan aktivitas hidupnya yaitu tercapainya ketiga maslahah yang meliputi maslahah dharuriyat, maslahah hajiyat dan maslahah tahsiniyat, meskipun mungkin sulit untuk mencapai ketiganya dalam waktu yang bersamaan. Pencapaian ketiga maslahah tersebut merupakan hal yang sangat ideal. Namun demikian, jika ketiganya tidak bisa dicapai maka maslahah yang pertama yaitu maslahah dharuriyat merupakan hal yang harus diperjuangkan oleh seorang individu dalam melaksanakan segala aktivitas hidupnya.

\section{Nilai Agama dan Perilaku Etika Islami dalam Berkonsumsi}

Islam telah memberikan tatanan nilai (etika atau akhlak) dalam berkonsumsi yang disebut etika berkonsumsi. Etika adalah adat kebiasaan (Harahap, 2011). Etika mengacu pada aturan tentang mana yang benar dan yang salah, mana yang baik atau tidak baik. Dari pengertian aslinya, maka yang dikatakan baik atau tidak baik, salah atau benar itu bila sesuai dengan kebiasaan masyarakat setempat (Yulianita, 2002). Namun dalam pandangan Islam ukuran benar dan salah harus mengacu pada nilai-nilai ajaran AlQuran maupun contoh Rasulullah. Kebenaran umum yang berlaku di masyarakat harus dikonfirmasi terlebih dahulu dengan syariah (Amaliah dkk., 2013; Effendi, 2013).

Nilai-nilai agama akan mengarahkan sikap dan perilaku yang lebih etis dalam hidup seorang individu (Amaliah, 2014). Barro dan Rachel M. McCleary, (2003) menemukan nilai keagamaan memengaruhi karakter pribadi seorang individu yang kemudian memengaruhi kinerja keseluruhan dari individu yang bersangkutan. Lebih lanjut, Salarzehi et.al. (2011) menemukan nilai spiritualitas individu dan organisasi mempunyai hubungan yang berarti dengan pola konsumsi pegawai.

Dalam penelitian sebelumnya, Muafi (2003:8) menemukan keyakinan atas nilainilai agama berimplikasi terhadap motivasi spiritual seorang individu. Memahami nilainilai agama secara utuh akan menjadi faktor pendorong bagi seorang individu untuk berperilaku sesuai nilai-nilai keyakinannya. Nizami dalam Ancok (2011: 70) dan Sholeh (2000: 303) menemukan kepatuhan dalam beragama dengan keseimbangan fisik dan mental yang lebih baik. Temuan ini sejalan dengan hasil Beehr, Johnson dan Nieva (1995: 5), di mana ketaatan beragama (religiosity) berhubungan dengan kualitas hidup. Artinya seorang individu yang patuh dan taat beragama akan memiliki jiwa dan raga yang seimbang yang kemudian akan berefek pada tingkat hidup yang berkualitas.

Menurut Ibnu Khaldun, kepuasan seorang individu dalam aktivitasnya (termasuk dalam konsumsi) sangat tergantung pada tingkatan hatinya. Dalam hal ini, Ibnu Khaldun membuat tiga tingkatan hati yaitu tingkatan hati ammara, tingkatan hati lawama dan tingkatan hati mutmainna (Iqbal, 2012).

Tingkatan hati ammara, yaitu orang yang selalu memperturutkan hawa nafsunya pada hal-hal yang bersifat negatif. Dalam aktivitas konsumsi, nafsu ammara ini akan tercermin dalam bentuk perilaku boros, mubazair, kikir, bermewah-mewahan dalam 
konsumsi serta perilaku suka menjebakan diri pada hutang dalam memenuhi keinginan konsumsinya. Orang dengan hati ammara akan merasa puas dalam hidupnya jika segala keinginannya terpenuhi meskipun harus bertentangan dengan nilai-nilai agama.

Sementara itu, tingkatan hati lawama (self reproaching psyche), yaitu seorang individu menyadari akan kejahatan, kemudian ia akan menahannya serta berdoa dan memohon ampunan kepada Allah dan bertaubat untuk mendapatkan keselamatan dalam hidupnya. Dalam tingkatan hati lawama seorang individu akan berusaha memilih cara berkonsumsi yang sesuai dengan nilai-nilai agama di antaranya mengonsumsi segala sesuatu secukupnya, menghindar dari barang yang haram dan riba, memilih barang yang memenuhi unsur halal dan baik (halalan toyibah). Seorang individu akan menghindar mengonsumsi barang yang tidak jelas asal usulnya serta tidak pasti mendapatkanya.

Tingkatan hati tertinggi (Mutmainna -the righteous psyche), yaitu tingkatan hati telah mencapai kedamaian dan kepuasaan serta mampu menguasai diri dari kesenangan. Seorang Muslim yang mempunyai tingkatan hati ini akan mempunyai spiritualitas yang tinggi di mana apapun yang dilakukannya semata-mata karena Allah. Seorang individu yang memiliki hati mutmainna akan merasa senang hatinya jika bisa berbagi banyak dengan saudara-saudaranya yang kekurangan. Individu yang memiliki hati mutmainna akan merasa resah jika melihat saudaranya dalam kesusahan serta tidak bisa memenuhi kebutuhan dasarnya secara layak. Dalam berkonsumsi orang yang berhati mutmainah tidak lagi memikirkan dirinya, serta lebih senang berbagi dengan orangorang yang membutuhkannya dan orang banyak. Orientasi konsumsi untuk mencapai maslahah.

Menurut Abdul Manan (1997), ada 5 prinsip konsumsi yang Islami yaitu (1) Prinsip Keadilan, prinsip ini mengandung arti ganda mengenai mencari rizqi yang halal dan tidak dilarang hukum. Firman Allah dalam QS AlBaqarah ayat 173; (2) Prinsip Kebersihan, makanan harus baik dan cocok untuk dimakan, tidak kotor ataupun menjijikkan yang dapat merusak selera dan menimbulkan penyakit; (3) Prinsip Kesederhanaan, prinsip ini mengatur perilaku manusia mengenai makan dan minuman yang tidak berlebihan Firman Allah dalam QS Al-A'raaf 31; (4) Prinsip kemurahan hati, dengan menaati perintah Islam tidak ada bahaya maupun dosa ketika kita memakan dan meminum makanan halal yang disediakan Tuhannya. Seperti dalam Firman Allah dalam QS Al-Maidah 96; (5) Prinsip moralitas, seorang muslim diajarkan untuk membaca basmallah dalam memulai suatu kegiatan dan mengakhirinya dengan mengucap hamdallah.

Dengan demikian agar setiap individu mampu menahan diri dalam kegiatan konsumsinya maka individu yang bersangkutan harus tunduk dan patuh pada nilai-nilai dan moral agama dalam berkonsumsi. Yusuf Qardhawi (1997), mengungkapkan ada sejumlah panduan perilaku etis Islami dalam berkonsumsi yaitu: (1) Menafkahkan harta dalam kebaikan dan menjauhkan diri dari kekikiran. Islam telah mengatur cara menafkahkan harta yang sesuai dengan syariah yaitu: menggunakan harta secukupnya, wajib membelanjakan harta, sasaran dalam membelanjakan harta yaitu untuk fisabilillah dan untuk dirinya dan keluarganya; (2) Islam melarang tindakan mubazir. Untuk mencegah terjadinya kemubaziran, Islam memberikan tuntunan dalam berkonsumsi yaitu menjauhkan diri dari berhutang, menjaga aset yang pokok dan mapan, tidak hidup bermewah-mewahan,tidak berlaku boros, menghambur-hambur harta. Perbuatan ini, menurut Qardhawi (1997), termasuk kriteria menghambur-hamburkan uang yang dilarang oleh Rasulullah; (3) Batasan Islam dalam menggunakan harta. Batasan dalam segi kualitas yaitu Islam melarang membelanjakan harta yang dapat memabukkan dan menimbulkan kerusakan pada tubuh dan akal. Adapun pembatasan secara kuantitas yaitu membatasi dari sisi jumlah yang akan menjebakkan manusia pada hutang. Orang yang suka berhutang adalah orang yang berakhlak buruk. Rasulullah bersabda bahwa, Seseorang jika berhutang maka ia akan berbohong dalam berkata dan ingkar jika berjanji. Selain itu, Priyanto (2006) menambahkan etika berkonsumsi adalah sebagai berikut: (1) Jenisnya yaitu konsumsi harus diarahkan untuk barang-barang yang halal lagi baik, yang meliputi: Zatnya, prosesnya, dan cara mendapatkannya; (2) Kemanfaatanya barang yang dikonsumsi yaitu memberikan manfaat tidak hanya untuk dirinya tetapi juga orang lain.

\section{Karakteristik Responden}

Responden dalam penelitian ini adalah pegawai yang bekerja di lingkungan pendidikan 
tingkat SMA yang meliputi para guru, tata usaha serta staf administrasi yang berjumlah 100 orang yang diambil dari sepuluh sekolah menengah tingkat atas dan kejuruan yang ada di wilayah kerja Kota Bandung yaitu SMAN 8, SMAN 10, SMAN 14, SMKN 2, SMKN 3, MAN 1, SMA Centauri, SMA Muhammadiyah, SMA Darul Hikam dan SMA PGII. Dalam penelitian, dua kelompok SMA yaitu SMA dengan latar belakang keagamaan dan SMA umum. Namun, meskipun SMA umum tidak memiliki latar keagamaan yang kental, mereka seorang juga Muslim. Dengan demikian, perilaku beragama dari para pegawai bersifat homogen karena pada umumnya para pegawai ini sudah belajar agama sejak kecil.

Sebagian besar responden memiliki latar pendidikan S1 (77\%) dan Magister $(14 \%)$. Responden telah bekerja cukup lama yaitu 26-30 tahun. Tingkat pendidikan yang relatif tinggi dipadu dengan pengalaman kerja yang lama tentunya akan berimbas pada tingginya pendapatan para pegawai di Tingkat SMA di Kota Bandung. Kondisi ini tentunya akan berpengaruh pada perilaku pegawai dalam mengalokasikan pendapatannya.

\section{Mengembangkan Kebaikan dan Tidak Kikir dalam Konsumsi}

Islam mengajarkan untuk mengembangkan kebaikan dan tidak bersifat kikir dalam berkonsumsi. Dari hasil pembobotan tujuh indikator mengembangkan kebaikan dan tidak kikir dalam berkonsumsi terkategori tinggi dengan skor rata-rata 177 . Sedangkan jika dilihat dari hasil pembobotan individu tidak ada perbedaan yang nyata tentang perilaku konsumsi islami dari para pegawai yang bekerja di SMA Islam maupun SMA Umum. Namun demikian, dalam beberapa hal, pegawai yang bekerja di SMA Islam lebih senang membeli barang-barang untuk kebutuhan masyarakat umum serta untuk orang-orang yang membutuhkan. Artinya, pemahaman yang baik tentang konsumsi sebagaimana dijelaskan dalam Al-Quran yang berbunyi bahwa dalam setiap pendapatan yang diterima seseorang ada hak orang lain benar-benar dipahami oleh para pegawai yang bekerja di SMA Islam dibandingkan pegawai yang bekerja di SMA Umum di Kota Bandung. Para pegawai merasa senang jika bisa berbagi dengan orang-orang yang membutuhkan dan tidak mampu. Para pegawai meyakini bahwa Allah akan melipatgandakan harta yang telah dibelanjakan secara ikhlas untuk agama maupun orang-orang yang kurang beruntung.
Selain itu, para pegawai yang bekerja di SMA Islam lebih senang untuk menafkahi dirinya dengan menggunakan uangnya sendiri. Menurut mereka tangan di atas lebih baik dibandingkan dengan tangan di bawah. Memberi lebih banyak dibandingkan menerima pemberian orang lain. Para pegawai mengaku meskipun kewajiban menafkahi keluarga adalah laki-laki namun para pegawai tidak segan untuk mengulurkan pendapatanya untuk memenuhi kebutuhan keluarga dan dirinya. Dengan demikian, para pegawai senang jika bisa berbagi lebih banyak untuk keluarganya, karena tujuan pegawai bekerja adalah untuk menyenangkan seluruh anggota keluarganya. Menurut pegawai, sebelum memuliakan orang lain maka mereka akan memuliakan keluarganya terlebih dahulu.

Terkait dengan perilaku belanja secukupnya, ternyata ada kesamaan perilaku dari pegawai yang bekerja di SMA Islam maupun SMA Umum, di mana para pegawai mengaku akan belanja secukupnya saja, tidak berlebihan dan juga tidak kikir (seimbang) sebagaimana dijelaskan oleh Rasulullah yaitu untuk berhenti makan sebelum kenyang. Artinya, sebagai manusia harus bisa menahan diri untuk tidak berlaku berlebihan sehingga tidak terjebak dalam kesulitan yang sebenarnya diciptakan sendiri sebagaimana dijelaskan dalam Surat Al-Furqan ayat 67:

"Dan orang-orang yang apabila membelanjakan (harta), mereka tidak berlebih-lebihan, dan tidak pula kikir dan apabila belanja di tengah-tengah antara demikian."

Lingkungan yang agamis turut membentuk sikap dan perilaku etis keagamaan dari seorang individu. Individu yang berada dalam lingkungan yang agamis cenderung lebih senang untuk membantu orang lain dan cenderung lebih mementingkan kepentingan bersama di atas kepentingan individunya. Hal ini sejalan dengan temuan dari Muafi (2003: 8) dan Amaliah \& Westi Riani (2011) di mana lingkungan agamis dan keyakinan atas nilai-nilai agama berimplikasi terhadap motivasi spiritual seorang individu untuk menjalankan kehidupan sesuai dengan nilainilai agama yang dipahaminya. Pemahaman yang baik atas nilai-nilai agama akan menjadi faktor pendorong bagi seorang individu untuk melakukan tindakan-tindakan sebagaimana yang diajarkan agamanya. Lebih lanjut Beehr, Johnson dan Nieva (1995: 5), menemukan ketaatan beragama (religiosity) juga berhubungan dengan kualitas hidup 
yang lebih baik. Individu yang taat beragama tidak hanya akan memikirkan kepentingan dirinya tetapi juga kepentingan orang lain. Kepentingan lahir tetapi juga batin dan agamanya.

\section{Tidak Mubajir dalam Berkonsumsi}

Secara rata-rata, pemahaman pegawai SMA di Kota Bandung atas konsep tidak belaku mubajir dalam berkonsumsi terkategori cukup dengan total skor adalah 110. Ada suatu pemahaman yang menganggap membelanjakan uangnya untuk barang yang sudah dimilikinya tidak dipahami sebagai kemubajiran dan dianggap sebuah kewajaran. Padahal Islam sudah menggariskan dalam berkonsumsi harus melihat manfaat dari barang yang dikonsumsinya. Para pegawai mengaku seringkali terbujuk dengan iklan dari suatu produk, membeli barang yang sama karena harganya lebih murah serta memaksakan diri berhutang karena merasa malu jika tidak mengikuti trend yang ada. Perilaku seperi ini jika dibiarkan akan menjadi hal yang biasa dan akan sangat memengaruhi keuangan rumah tangga.

Sulitnya memisahkan antara konsep kebutuhan dan keinginan inilah yang seringkali mendorong seorang individu merasakan bahwa tindakan menghabiskan guna suatu barang pada hal-hal yang kurang jelas manfaatnya dianggap sebagai sebuah kewajaran. Pegawai di SMA merasa bahwa apa yang diinginkannya adalah sebuah kebutuhan yang harus dipenuhi. Padahal dasar dari keduanya adalah berbeda. Keinginan dasarnya adalah nafsu (kepuasan sesaat) sedangkan kebutuhan dasarnya adalah maslahat di mana jika dipenuhi akan memberikan manfaat yang besar bagi yang mengonsumsinya. Agama memberikan arahan hanya keinginan-keinginan yang memberikan manfaat terbesar yang harus dipenuhi oleh setiap individu. Dalam surat Ali Imran ayat 14 Allah menyindir manusia betapa tidak terbatasnya keinginan manusia:

"Dijadikan indah pada pandangan manusia kecintaan terhadap apa-apa yang diinginkan yaitu wanita-wanita, anakanak, harta yang banyak dari jenis perak, kuda pilihan, binatang-binatang ternak dan sawah ladang. Itulah kesenangan hidup di dunia dan di sisi Allahlah tempat kembali yang baik."

Selain itu, Rasulullah pernah menyindir manusia di mana ketika seorang anak Adam diberi satu bukit pasti akan meminta dua bukit, dan ketika diberi dua bukit maka akan meminta tiga bukit dan terus seperti itu, hingga raganya terkubut tanah (meninggal). Hal ini menandakan manusia memiliki keinginan yang tidak terbatas. Jika keinginankeinginan tersebut tidak dikendalikan maka manusia akan terjebak pada kerusakan. Agama dapat menjadi filter dari tindakantindakan yang tidak sesuai dengan agama (Chapra, 2008).

Perilaku berlebihan dan cenderung mubazir terlihat pula dalam merayakan hari keagamaan. Para pegawai mengganggap sebagai sebuah kewajaran jika dalam menyambut hari raya dengan menggunakan atribut-atribut yang spesial. Alasan yang mengemuka karena hari raya hanya terjadi sekali dalam satu tahun dan tujuannya adalah ibadah. Pembenaran inilah yang seringkali

Beli barang untuk menyenangkan keluarga

Manfkahi diri sendiri

Beli barang untuk masyarakat

Beli untuk orang yang membutuhkanya

Beli barang tidak hanya diri sendiri

Beli barang secukupnya

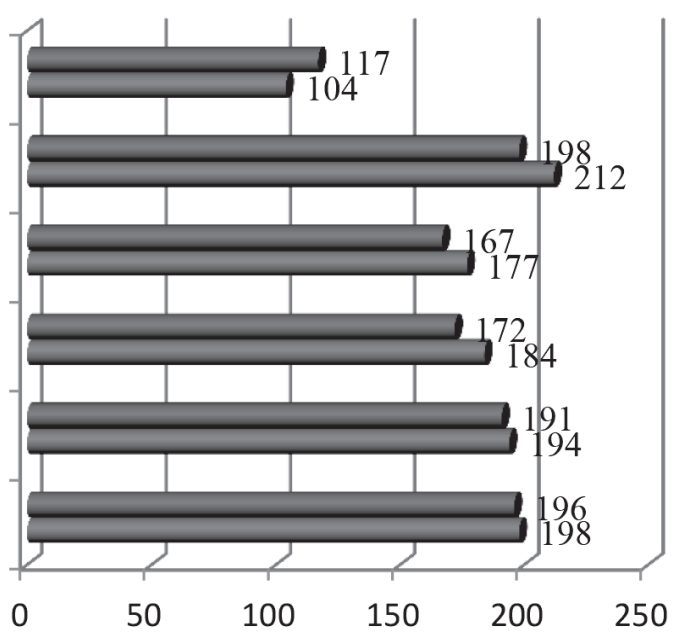

- Umum

- Islam

Gambar 1. Tanggapan Responden tentang Konsumsi untuk Kebaikan dan Tidak Kikir

Sumber: diolah dari data primer 
membawa perekonomian ke dalam kondisi yang sulit seperti tingginya inflasi, kerusakan alam, polusi maupun limbah. Sesungguhnya, Allah telah menunjukkan ketidaksukaanya dan mengancam manusia yang suka berlebihan, bermegah-megahan dan boros sebagaimana tertera dalam Surat At-Takasur ayat 1-8 yaitu Bermegah-megahan telah melalaikan kamu masuk ke dalam kubur... Dalam surat yang lain Allah mengecam pemboros-pemboros sebagai saudara setan, sebagaimana dijelaskan dalam Al-Quran Surat Al-Isra ayat 27:

"Sesungguhnya pemboros-pemboros itu adalah saudara-saudara setan dan setan itu sangat ingkar pada Tuhan."

\section{Memilih Barang yang Halal dan Baik dalam Berkonsumsi}

Islam telah memberikan tuntunan kepada manusia untuk memilih barangbarang yang akan dikonsumsi yaitu tidak hanya halal tetapi juga harus baik. Artinya, barang-barang yang dikonsumsi harus halal dalam pandangan Allah dan Rasulullah. Selain itu, barang yang dikonsumsi harus baik dari sisi kandungan gizi dan nutrisinya serta tidak mengandung bahan-bahan yang dapat mengganggu kesehatan manusia baik dalam jangka pendek maupun jangka panjang. Keharusan mengonsumsi barang yang halal dan baik ini telah ditegaskan Allah dalam surat Al-Baqarah ayat 168 berbunyi:

\begin{abstract}
"Wahai manusia makanlah makanan yang halal dan baik yang terdapat di bumi, dan janganlah kamu mengikuti langkahlangkah setan, sesungguhnya setan itu musuh yang nyata."
\end{abstract}

Dari hasil pengolahan data, total skor untuk point ini berada dalam kategori tinggi (199). Artinya, para pegawai yang bekerja di SMA di Kota Bandung sudah memiliki kesadaran yang tinggi dalam memilih barangbarang yang akan dikonsumsinya. Ini tampak dari pengakuan pegawai yaitu membeli barang karena bahan pembuatnya baik, tidak membahayakan dirinya dan keluarganya serta tidak mengganggu kesehatan baik dalam jangka pendek maupun jangka panjang. Pengetahuan yang baik dari para pegawai dapat mengurangi risiko yang disebabkan oleh tindakan curang para pedagang yang tidak bertanggung jawab seperti menggunakan bahan pengawet mayat, zat pewarna kain, serta bahan baku yang sudah kadaluwarsa, ayam tiren dan lain-lain. Perilaku ini tidak hanya membahayakan kesehatan tetapi juga akidah dari para penggunanya. Para pegawai memiliki kesadaran untuk mengonsumsi barang yang halal, tidak mengandung riba, tidak ada unsur spekulasi serta ketidakpastian dalam proses mendapatkannya.

\section{Masalahah dalam Berkonsumsi}

Tujuan yang ingin dicapai dalam kehidupan ini adalah maslahah yaitu selamat di dunia dan selamat di akhirat. Untuk mencapai kemaslahatan maka manusia harus mendasarkan segala aktivitasnya pada nilainilai agama serta segala hal yang dicontohkan Rasulullah.

Secara umum, para pegawai di SMA Kota Bandung menanggapi maslahah dalam konsumsi sangat tinggi dengan bobot 211 . Ini mengindikasikan bahwa pemahaman pegawai atas konsep maslahah dalam berkonsumsi sangat baik. Dalam berkonsumsi para pegawai tidak hanya memikirkan manfaat bagi dirinya sendiri tetapi juga manfaat bagi orang lain dan lingkungannya. Munculnya kerusakan alam serta berbagai persoalan ekonomi seringkali

Beli barang mahal untuk HR. keagamaan

Membiarkan barang tidak terpakai

Malu tidak ikut tren

Beli meskipun tidak butuh

Beli dengan bergadai

Beli dengan berhutang

Beli barang karena iklan

Beli barang yang sama karena harganya.

Beli barang karena kualitasnya

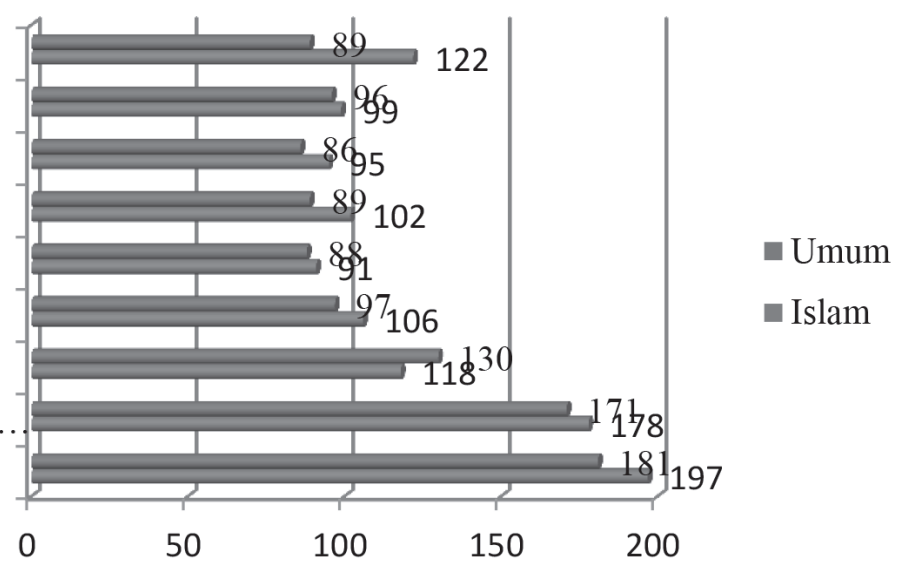

Gambar 2. Tanggapan Responden tentang Tindakan Mubajir dalam Berkonsumsi 


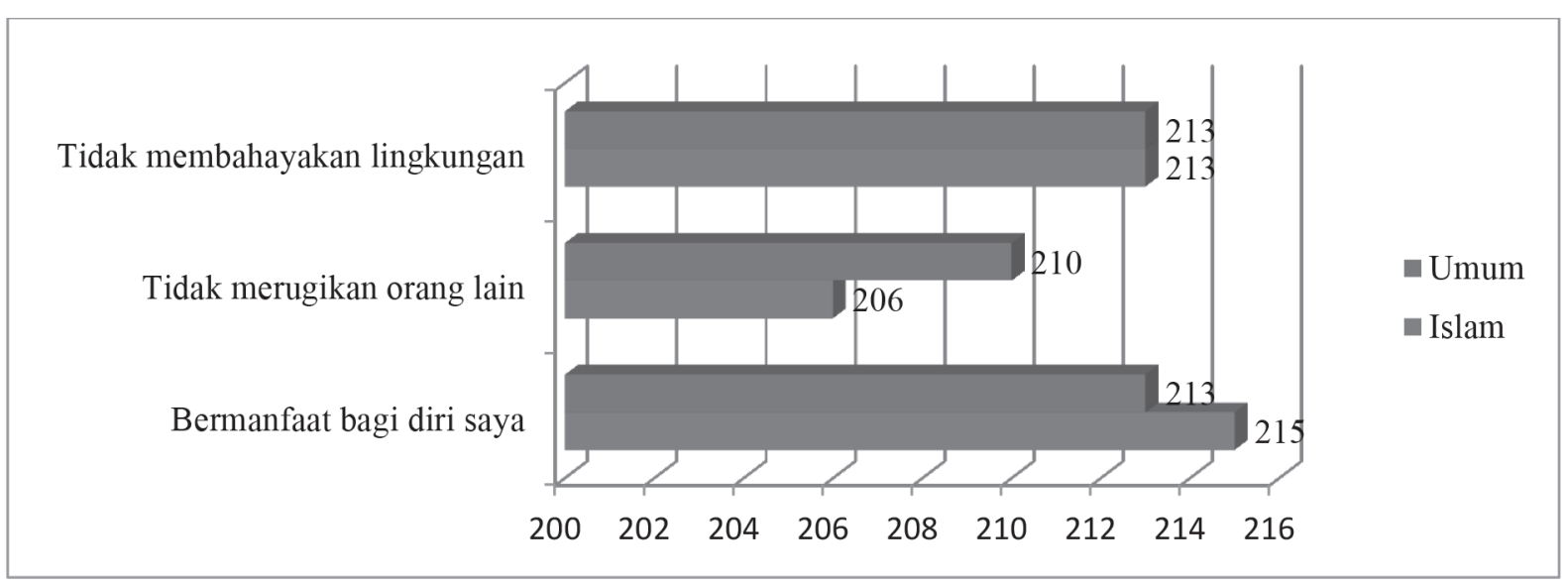

Sumber: diolah dari data primer.

\section{Gambar 4. Tanggapan Responden tentang Maslahah dalam Konsumsi}

terjadi karena banyak manusia yang hanya mementingan kepentingan dirinya sendiri dan melupakan keberadaan mahkluk lainnya. Efeknya terjadilah eksploitasi terhadap alam secara besar-besaran yang berakibat pada rusaknya ekosistem. Padahal Allah dan Rasulullah telah memberikan tuntunan untuk melakukan konsumsi secara adil dan bermoral.

Keadilan dalam konsumsi artinya manusia tidak berperilaku hanya dengan memperturutkan keinginannya, tetapi harus mempertimbangkan dampak dari apa yang dilakukan bagi dirinya, orang lain dan lingkungannya. Keadilan dalam berkonsumsi telah dijelaskan Allah dalam Al-Quran Surat Al-Baqarah ayat 173, yang berbunyi:

\begin{abstract}
"Sesungguhnya Dia hanya mengharamkan atasmu bangkai, darah, daging babi dan daging hewan yang disembelih dengan menyebut nama selain Allah. Tetapi barangsiapa terpaksa memakannya, bukan karena menginginkanya dan tidak melampaui batas, maka tidak ada dosa baginya, Sesungguhnya Allah Maha pengampun dan Maha penyayang."

Dilarangnya bangkai, darah serta daging babi dikarenakan barang-barang tersebut mengandung berbagai bakteri dan parasit yang akan membahayakan kesehatan si pemakannya. Larang Allah tersebut memberikan manfaat untuk kehidupan saat ini dan yang akan datang. Selain harus bertindak adil maka manusia juga harus memerhatikan nilai-nilai moral dalam berkonsumsi sebagaimana yang telah dicontohkan oleh Rasulullah. Nilai-nilai moral maupun akhlak merupakan tuntunan yang tidak terpisah dari akidah dan syariah. Ketiganya menjadi pilar yang tidak terpisah dalam kehidupan manusia.
\end{abstract}

Saat ini, rusaknya tatanan kehidupan di bumi ini dikarenakan antara akidah, akhlaqk dan syariah terpisah dari kehidupan manusia. Dalam berdagang manusia memisahkan ahlaq dengan keuntungan. Efeknya banyak pedagang menghalalkan segala cara untuk mendapatkan keuntungan maksimum. Begitupun dalam konsumsi, manusia seringkali memisahkan akhlaq dengan konsumsinya, sehingga seorang individu membeli barang secara berlebihan, boros serta bersikap riya. Padahal Rasulullah telah memberikan tuntunan akhlak yang sangat baik dalam berkonsumsi yaitu meniatkan seluruh kegiatan konsumsi untuk mendapatkan ridho Allah. Oleh karenanya, konsumsi harus diawali dengan doa dan diakiri pula dengan doa.

\section{Simpulan dan Saran}

Secara umum, tidak ada perbedaan perilaku konsumsi Islami dari pegawai yang berkerja di SMA Islam dan SMA Umum di Kota Bandung. Hal ini dapat dilihat dari tingginya skor indikator kebaikan dan tidak bersifat kikir dalam berkonsumsi, memilih barang halal dan baik dalam berkonsumsi serta maslahah dalam berkonsumsi.

Tingginya kesadaran ini tidak terlepas dari latar pendidikan yang baik, lingkungan kerja yang kondusif serta pendapatan yang memadai. Namun demikian, masih ada beberapa perilaku yang kurang sesuai dengan nilai-nilai agama seperti melakukan tindakan mubajir dalam berkonsumsi yang disebabkan sering tergiur dengan iklannya, program potongan harga serta gengsi pribadi. Dualisme perilaku pegawai ini, kemungkinan besar terjadi karena pegawai belum dapat membedakan antara konsep kebutuhan dan keinginan, sehingga tindakan menggunakan guna suatu barang bukan berdasarkan azas 
manfaat yang didapat dari barang yang dikonsumsinya, tetapi lebih karena barang tersebut dapat memberikan kepuasan yang paling besar. Oleh karena itu, penambahan pengetahuan baik pengetahuan umum maupun agama harus dilakukan secara terus menerus agar menjadi konsumen yang cerdas.

\section{Daftar Pustaka}

A. Manan, (1997), Teori dan Praktek Ekonomi Islam, Yogyakarta: Dana Bhakti Wakaf

Al-Ghazali, Imam, (2009), Ihya Ulumuddin: Menghidupkan Ilmu-ilmu Agama,Buku 1, Penerjemah Purwanto, Bandung: Penerbit MARJA

Amaliah, Ima, Westi Riani, Aan Julia, (2013), "Pengaruh Nilai-nilai Islam terhadap Kinerja Kerja," Mimbar: Jurnal Sosial dan Pembangunan, Vol. 29, No. 2, Desember, Bandung: P2U-LPPM Unisba

Amaliah, Ima, (2014), Faktor-faktor yang Memengaruhi Etika Kerja dan Motivasi Kerja Islami serta Implikasinya terhadap Kepuasan Kerja Islami di UKM Kerajinan Bordir Kota Tasikmalaya,Disertasi, Jakarta: Universitas Trisakti

Ancok, Jamaludin, (2011), Psikologi Islami: Solusi Islam atas Problem-problem Psikologi, Yogyakarta: Pustaka Pelajar, h. 70-76

Asytuti, Rinda, (2011), "Rekonstruksi Ekonomi Islam dalam Perilaku dan Motivasi Ekonomi," Pekalongan: RELIGIA, Vol. 14, No. 1, April, h.75-92

Barro dan Rachel M. MacCleary, (2003), Religion and Economic Growth across Countries, American Sociological Review, Vol. 68, No. 5, pp. 760-781

Beehr, T.A., Johnson, L.B. \& Nieva R., (1995), "Occupational Stress: Coping of Police and Their Spouse," Journal of Organizaional Behavior, 16, P.3-25

Chapra, Umar, (2008)," The Islamic Vision of Development in the Light of Maqashid alShariah," Occasional Paper Series 15, The International Institute of Islamic.

Effendi, Rahmat., s. Komarudin dan Nandang HMZ, (2013), "Memperbaiki Gonjang Ganjing Akhlak Bangsa," Bandung: AlFikriis, h. 9-31.
Harahap S. Sofyan, (2011), "Etika Bisnis dalam Perspektif Islam," Jakarta: Salemba Empat, h. 15-52.

Iqbal , Muhammad Noor, Suharnomo, (2012), "Motivasi Islam dan Motivasi Prososial pada Lembaga Amil Zakat; Studi pada Para Pegawai Post Keadilan Peduli Ummat (PKPU) Cabang Semarang," Diponegoro Journal of Managemen, Volume 1, Nomor 2, h. 415-429 http://ejournal-s1.undip. ac.id/index.php/dbr.

Karim, Adiwarman, (2007) "Ekonomi Mikro Islami," Jakarta: CV. Rajagrafindo Persada

Kara, Muslim, 2012," Pemikiran Al-Syatibi tentang Maslahah dan Implementasinya dalam Pengembangan Ekonomi Syariah," Jurnal ASSETS, Volume 2, No. 2, h. 173184.

Khaf, Monzer, (1995) Ekonomi Islam: Telaah Analitik terhadap Fungsi Sistem Ekonomi Islam, Penerjemah Machnun Husein, Yogyakarta: PT. Tiara Wacana.

Muafi, (2003), "Pengaruh Motivasi Spiritual Karyawan terhadap Kinerja Religius: Studi Empiris di Kawasan Rungkut Surabaya (SIER)," Yogyakarta: Jurnal Siasat Bisnis, Vol. 1 No. 8, h. 01-18.

Putong, Iskandar, (2009), "Economics: Pengantar Mikro dan Makro," Jakarta: Penerbit Mitra Wacana Media.

Qardhawi, Yusuf, (1997), "Ekonomi Islam: Norma dan Etika," Jakarta: Gema Insani Press, h. 104-117.

Robbins, Stephen P., Timothy A. Judge, (2009),'Organization Behavior," $12^{\text {th }}$ Edition, Pearson Education, pp. 220-253.

Salarzehi, Habibollah, Hamed Aramesh and Mostafa Mohammadi, (2011), "organization Spirituality and Its Impact on Consumption Model Of Employee in Govermental Organizations in Iran (Case Study)," International Journal of Business and Management, Vol. 6, No. 1; January.

Sarwono, (2009), Analisis Perilaku Konsumen Perspektif Ekonomi Islam, INNOFARM: Jurnal Inovasi Pertanian Vol.8, No. 1, 41 $-53$.

Yulianita, Neni, (2002)," Implementasi Etika di Era Globalisasi," Bandung, MIMBAR:Jurnal Sosial dan Pembangunan, Vol XVIII, No. 4, Maret, h. 459-461. 